\title{
Hepatitis $C$ drug prescriptions and Medicaid policies--four states, Indian health care system, USA 2018
}

\author{
Brigg Reilley ${ }^{1 *}$, Matt Miller², Matt Hudson ${ }^{3}$ Rick Haverkate ${ }^{2}$ and Jessica Leston ${ }^{1}$
}

\begin{abstract}
Medicaid, the state-level public insurance in the United States, has widely differing criteria treatment for hepatitis C virus (HCV) such as stage of liver fibrosis, documented sobriety, and specialist consultation. In a rural health network, facilities located in two less restrictive states prescribed HCV drugs at a significantly higher rate than two more restrictive states (rate ratio 4.7, $\mathrm{Cl}$ 2.6-8.5). Prescription rates per population were highly associated with HCV treatment policies.
\end{abstract}

\section{Introduction}

In the United States, an estimated 2.4 million persons have chronic hepatitis $\mathrm{C}$ virus (HCV) infection [1], and the number of deaths from HCV-related mortality is greater than those from HIV and TB combined [2]. Treatment of $\mathrm{HCV}$ with direct acting antivirals (DAAs) can cure over $95 \%$ of patients with $\mathrm{HCV}$, and cure has been shown to greatly reduce liver-related as well as allcause mortality [3, 4]. The medical benefits of early treatment of treatment of $\mathrm{HCV}$, before any liver fibrosis has occurred, further improves medical outcomes for $\mathrm{HCV}$ patients [5]. However, access to treatment has been limited, often due to treatment criteria that are at least partially attributable to the cost of drugs [6].

American Indian and Alaska Native (AI/AN) people have over twice the national rate of $\mathrm{HCV}$ related mortality, making access to treatment among this population a priority [7]. Surveillance data from the Indian Health Service (IHS), the federal agency that provides direct medical care to AI/AN communities, documented approximately 30,000 unique patients with $\mathrm{HCV}$, with significant differences in HCV burden by region [8].

The overall Indian health care system is comprised of federal (IHS), tribal, and urban Indian facilities. It is the largest health system provider to AI/AN communities, serving approximately 2.6 million persons in 37 states. State Medicaid programs are a key public insurer for an important proportion of patients in this health network. However, state Medicaid programs vary greatly in $\mathrm{HCV}$ treatment eligibility criteria, with some states requiring late stage liver fibrosis, specialist consultation, documented periods of sobriety and other qualifications prior to HCV treatment approval [9]. These eligibility requirements for treatment of a confirmed diagnosis of an infectious disease are thought to be unique to $\mathrm{HCV}$, and are not in alignment with clinical recommendations [10].

We examined prescription data to determine if state Medicaid policy correlated with significant differences for facilities of the Indian health care system.

\footnotetext{
*Correspondence: breilley@npaihb.org; brigg.reilley@ihs.gov

This Letter to the Editor documents the impact of state level policies on access to treatment for hepatitis $C$ virus in a large rural health network serving American Indians/Alaska Natives. Prescription data from two states (Washington, New Mexico) with less restrictive treatment policy showed significantly higher rates of HCV prescriptions per population than adjacent states (Oregon, Arizona) with more restrictive policies.

${ }^{1}$ Northwest Portland Area Indian Health Board, 2121 Broadway Suite 300,

Portland, OR 97201, USA

Full list of author information is available at the end of the article
}

\begin{abstract}
Methods
For purposes of comparison, we considered all state pairs served by the Indian health care system that had notably differing $\mathrm{HCV}$ treatment eligibility in state Medicaid programs, were contiguous, and had similar Affordable Care Act Medicaid Expansion policies. For meaningful estimates, the states had to have at least 50, 000 tribal registrants served.
\end{abstract}


Table 1 Direct acting antiviral (DAA) HCV prescriptions by population served, Indian Health Service and tribal health facilities, Washington and Oregon, New Mexico and Arizona, 2018

\begin{tabular}{lllllr}
\hline Active Indian registrants & $\begin{array}{l}\text { DAA prescriptions } \\
\text { (28-day units) }\end{array}$ & $\begin{array}{l}\text { Prescriptions per } \\
100,000 \text { population }\end{array}$ & $\begin{array}{l}\text { Medicaid HCV drug } \\
\text { access grade }^{a}\end{array}$ & $\begin{array}{l}\text { DAA prescriptions rate } \\
\text { ratio (95\% Cl) }\end{array}$ \\
\hline WA & 127,167 & 116 & 91.2 & A- & $4.7(2.6-8.5)$ \\
OR & 61,530 & 12 & 19.5 & D & A \\
NM & 366,163 & 114 & 31.1 & A (3.3-6.8) \\
AZ & 601,817 & 40 & 6.7 & C+ & \\
\hline
\end{tabular}

${ }^{\mathrm{a}}$ Stateofhepc.org

Medicaid eligibility for HCV differ by criteria such as liver disease progression, substance use/sobriety requirements, and prescriber restrictions. We used an external, publicly available resource to assign a rating to $\mathrm{HCV}$ policy by state [5]. Tribal registrants are defined as enrolled members of the tribe within the geographic area served by the federal or tribal health facility. Registrant data was taken from the fiscal year 2018 IHS User Population Memorandum.

Prescription data were compiled via the IHS National Service Supply Center (NSSC), a central purchasing option for federal and tribal service units. These data record orders for HCV DAA prescriptions in 28-day units.

\section{Results}

Contiguous state pairs that met the inclusion criteria were New Mexico/Arizona and Washington/Oregon. These dyads showed a significant difference in prescription rates per 100,000 inhabitants. States with a better Medicaid rating (WA, NM) had a prescription rate 4.7 times higher than their comparison states (Table 1).

\section{Conclusions}

Prescriptions per patient population were significantly higher in states with less restrictive Medicaid policies, with a rate ratio of nearly five times compared to neighboring states with more restrictive criteria. In the long term, policy-related treatment disparities may result in measurable differences by state in rates of hepatocellular carcinoma, liver transplants, and other adverse outcomes. The disparity in prescription rates between the two less restrictive states (OR and NM) may be attributable to differences in HCV burden, as IHS data document the Southwest as the region with the lowest apparent HCV seroprevalence [8].

These results have limitations, in that some prescriptions may not be documented by NSSC data, and that prescriptions ordered are a proxy for $\mathrm{HCV}$ treatment initiation. However, there is no known systemic difference in access to care, patterns of Medicaid usage, clinical capacity, or other variable between the facilities in each state dyad. Medicaid policy is the single greatest variable known to influence initiation of $\mathrm{HCV}$ treatment for the facilities in this review.
There are indications that some states are reducing $\mathrm{HCV}$ treatment restrictions. For example, Arizona recently eliminated fibrosis requirements, and Oregon eliminated fibrosis and sobriety barriers; these reforms may increase future prescription rates. However, a majority of state Medicaid programs retain varying degrees of eligibility criteria unique to $\mathrm{HCV}$.

\section{Abbreviations \\ Al/AN: American Indian/Alaska Native; AZ: Arizona; DAA: Direct acting antiviral; HCV: Hepatitis C virus; IHS: Indian Health Service; NM: New Mexico; NSSC: National Service Supply Center; OR: Oregon; WA: Washington \\ Acknowledgments \\ The authors would like to acknowledge Tom Weiser, Sujata Joshi, and Paulina Deming for their contributions.}

\section{Authors' contributions}

$\mathrm{BR}$ analyzed the combined datasets and led the writing. $\mathrm{MM}$ and $\mathrm{MH}$ extracted and organized prescription data. $\mathrm{RH}$ was a major contributor to writing. JL led study inception and design. All authors read and approved the final manuscript.

Author information

Not applicable.

Funding

No special funding was used for this analysis.

\section{Availability of data and materials}

Prescription data from Indian Health Service are generally not available to the public unless approved by Institutional Review Board.

Ethics approval and consent to participate

This was deemed exempt as non-research as per the IHS Institutional Review Board.

Consent for publication

Not Applicable.

\section{Competing interests}

The authors declare that they have no competing interests.

\section{Author details}

${ }^{1}$ Northwest Portland Area Indian Health Board, 2121 Broadway Suite 300, Portland, OR 97201, USA. ${ }^{2}$ United States Indian Health Service, 5600 Fishers Lane, Rockville, MD 20857, USA. ${ }^{3}$ Johns Hopkins University School of Medicine, 733 N Broadway, Baltimore, MD 21205, USA.

Received: 12 November 2019 Accepted: 22 November 2019

Published online: 04 December 2019

\section{References}

1. Centers for Disease Control and Prevention, Hepatitis C factsheet https:// www.cdc.gov/hepatitis/hcv/hcvfaq.htm\#section1, Accessed 1 Oct 2019. 
2. Ly KN, Hughes EM, Jiles RB, Holmberg SD. Rising mortality associated with hepatitis C virus in the United States, 2003-2013. Clin Infect Dis. 2016;62(10): $1287-8$.

3. World Health Organization, Hepatitis C fact sheet, https://www.who.int/ news-room/fact-sheets/detail/hepatitis-c, Accessed 1 Oct 2019.

4. van der Meer AJ, Veldt BJ, Feld JJ, Wedemeyer H, Dufour JF, Lammert F, et al. Association between sustained virological response and all-cause mortality among patients with chronic hepatitis $\mathrm{C}$ and advanced hepatic fibrosis. JAMA. 2012;308(24):2584-93.

5. Backus LI, Belperio PS, Shahoumian TA, Mole LA. Direct-acting antiviral sustained virologic response: impact on mortality in patients without advanced liver disease. Hepatology. 2018;68(3):827-38.

6. Ward JW, Mermin JH. Simple, effective, but out of reach? Public health implications of HCV drugs. NEJM. 2015:2678-80.

7. Centers for Disease Control and Prevention, Surveillance for Viral Hepatitis, US, 2017 https://www.cdc.gov/hepatitis/statistics/2017surveillance/index. htm, Accessed 1 Oct 2019

8. Reilley, B, Leston J, Doshani M, et. al. Assessing disparities in the rates of HCV diagnoses within American Indian or Alaska native populations served by the US Indian Health Service, 2005-2015. J Community Health 43, no. 6 (2018): 1115-1118.

9. National Viral Hepatitis Roundtable, Center for Health Law and Policy Innovation, Harvard University, State of Hepatitis Medicaid Access" stateofhepc.org, Accessed 1 July 2019.

10. American Association for the Study of Liver Diseases and the Infectious Disease Society of America, When and in Whom to Initiate HCV Treatment, https://www.hcvguidelines.org/evaluate/when-whom, Accessed 2 Oct 2019.

\section{Publisher's Note}

Springer Nature remains neutral with regard to jurisdictional claims in published maps and institutional affiliations.

Ready to submit your research? Choose BMC and benefit from:

- fast, convenient online submission

- thorough peer review by experienced researchers in your field

- rapid publication on acceptance

- support for research data, including large and complex data types

- gold Open Access which fosters wider collaboration and increased citations

- maximum visibility for your research: over $100 \mathrm{M}$ website views per year

At BMC, research is always in progress.

Learn more biomedcentral.com/submissions 